\title{
HOW EXTREME WERE THE TORRENTIAL FLOODS IN SMALLER WATERSHEDS IN SERBIA IN SEPTEMBER 2014
}

\author{
${ }^{1}$ Ana Petrović, ${ }^{2}$ Sanja Manojlović, ${ }^{3}$ Stanimir Kostadinov \\ ${ }^{1}$ Geographical Institute „Jovan Cvijić“" of the Serbian Academy of Sciences and Arts, Belgrade, Serbia \\ ${ }^{2}$ University of Belgrade - Faculty of Geography, Belgrade, Serbia \\ ${ }^{3}$ University of Belgrade - Faculty of Forestry, Belgrade, Serbia \\ Corresponding email: a.petrovic@gi.sanu.ac.rs
}

\begin{abstract}
The September torrential floods in 2014 in the Eastern Serbia were a real disaster for local residents in municipalities of Kladovo, Negotin and Majdanpek. Meteorological extreme event caused the hydrological extreme event which led to declaration of the emergency situation in all three municipalities. The combined method of Soil Conservation Service and synthetic unit triangular hydrograph (SCS$\mathrm{SUH}$ ) is employed to compute the maximal discharges in small watersheds of Dupljanska reka and Manastirički potok, in order to assess the extremeness of September 2014 torrential flood events. Since the surface runoff is accompanied by intensive soil erosion on watershed slopes and the maximal discharges by sediment transport in river beds, estimation of mean annual sediment transport is also presented in this work. The September 2014 floods will remain historic given that they took 5 human lives and caused enormous material damage for local municipalities, so presented hydrological analysis should be taken as very important part of flood event documentation along with reports of municipalities' emergency headquarters.
\end{abstract}

Keywords: emergency situation, torrential flood, Dupljanska reka, Manastirički potok, Serbia

\section{Introduction}

From the aspect of natural hazards, the year 2014 will be remembered as cataclysmic for Serbia and local communities. The media all around world spread information about torrential floods in Serbia in May 2014. The cause of one of the most extreme torrential flood events was an above average rainy spring which along with the snow melting filled the infiltration capacity of soils. Such saturated soil cover could not receive the new extreme rainfall precipitation between $14^{\text {th }}$ and $16^{\text {th }}$ May which resulted in floods of sudden occurrence leaving extreme short time for warning and reaction. Torrential floods had extremely ruinous effects, especially in municipalities of Krupanj, Ljubovija and Loznica. This torrential flood event was one of the most extreme in Serbia (impacting large area in the Western and Central Serbia) since 1915 according to the Inventory of torrential floods in Serbia (Petrović et al. 2014). Later, in August there were torrential floods of several torrents nearby Banja Koviljača (the Western Serbia). 
Torrential floods in the Eastern Serbia on $15^{\text {th }}$ September 2014 will remain as historic due to devastating effects on local communities though this event did not get enough room in media. The hydrological analysis of torrential floods of the direct Danube tributaries (Podvrška, Velika Kamenica, Slatinska, Zamna and Mala Kamenica) is presented by Petrović et al. 2021. In this paper, we analyze the extremeness of the torrential floods of smaller watersheds of Dupljanska reka (Negotin municipality) and Manastirički potok (Kladovo municipality) which contributed to the overall cataclysmic situation.

Dupljanska reka and its tributaries flooded residential and economic buildings at the village Dušanovac. Two older persons were evacuated and two other persons were sheltered on higher floor. The number of damaged households were 753 and the population that experienced the damage from this flood event was 1618, according to the Emergency headquarter of the Municipality of Negotin. Đokanović (2016) discovered that the total of 30 landslides registered at the territory of the municipality of Kladovo were activated due to intense precipitation episode in the middle of September 2014. The landslide nearby monastery in the Manastirički potok watershed is registered as well as one more at the road to the monastery.

As Tošić et al. (2017) claimed, at almost all meteorological stations in Serbia the total annual precipitation in 2014 was the highest for the period 1961-2014. Meteorological station Negotin recorded $161.3 \mathrm{~mm}$ of rainfall on the $15 / 16^{\text {th }}$ September 2014 (measuring from 7 to $7 \mathrm{~h}$ ). There is also one more, an earlier daily rainfall extreme in the Eastern Serbia recorded by the RHMS Serbia (Republic Hydrometeorological Service of Serbia) and that is $211 \mathrm{~mm}$ in October 1955. Tošić and Unikašević (2014) showed that wet and dry periods become more frequent at the territory of Serbia after 1970, pointing also to more frequent rainfall extremes and consequently torrential flood events in hilly-mountainous regions.

Before 2014, the death toll of torrential floods in Serbia for the period from 1915 had a decreasing trend (Petrović et al. 2014). Death toll of May 2014 torrential floods in the Western and the Central Serbia reached 51, there were local torrential floods in the Western Serbia in August 2014 with 1 casualty, while the September 2014 torrential floods in the Eastern Serbia took 5 human lives. All three torrential flood events of different spatial scale caused the proclamation of the emergency situations.

\section{Study area}

The Dupljanska reka is a left tributary of Jasenička river (a direct right tributary of the Danube River). Given that the most of the direct runoff is generated in the upper part of a watershed with steeper slopes, for the purpose of this study the profile on Dupljanska reka is defined on the point where hilly area ends and flat area begins (Figure 1). The Manastirički potok is a left tributary of the Matka (a direct right tributary of the Danube River) and watershed is delineated up to confluence to the Matka. Morphometry of both studied watersheds is conducted in QGIS using digital elevation model and topographic maps and results are presented in Table 1. Watershed area of Dupljanska is around $16 \mathrm{~km}^{2}$ and Manastirički potok ca. $5 \mathrm{~km}^{2}$. Absolute slope of river bed, which is a ratio of the relative altitude difference between profile/confluence point and peak point, and watershed length, is more than double higher for Manastirički potok $(6.82 \%)$ than for Dupljanska reka (3.18\%). Mean slope of river bed is also higher for Manastirički potok (2.87\%). 
Table 1. Some morphometric parameters of observed watersheds

\begin{tabular}{|l|l|l|l|l|}
\hline \multicolumn{2}{|c|}{ Parameters } & Dupljanska reka & Manastirički potok & Unit \\
\hline $\mathrm{A}$ & Watershed area & 15.74 & 4.92 & $\mathrm{~km}^{2}$ \\
\hline $\mathrm{P}_{\mathrm{p}}$ & Peak point & 342 & 435 & $\mathrm{~m}$. a.s.1 \\
\hline $\mathrm{P}_{\mathrm{c}}$ & Confluence/ Profile point & 91 & 124 & m.a.s.1 \\
\hline $\mathrm{H}_{\mathrm{sr}}$ & Mean altitude & 254 & 289 & m.a.s.1 \\
\hline $\mathrm{L}$ & Watershed length & 7.88 & 4.56 & $\mathrm{~km}$ \\
\hline $\mathrm{S}_{\mathrm{a}}$ & Abs. slope of river bed & 3.18 & 6.82 & $\%$ \\
\hline $\mathrm{S}_{\mathrm{rb}}$ & Mean slope of river bed & 2.18 & 2.87 & $\%$ \\
\hline
\end{tabular}

Regarding the geology of observed watersheds, the tertiary clastic sediments are dominant geological substrates (78\%) in the watershed of Dupljanska reka and flysch sediments in the watershed of Manastirički potok (74\%). Tertiary clastic sediments have a share of $15 \%$ in the Manastirički potok watershed while metamorphic rocks cover $20 \%$ in the watershed of Dupljanska reka, which are secondary dominant geology substrates.

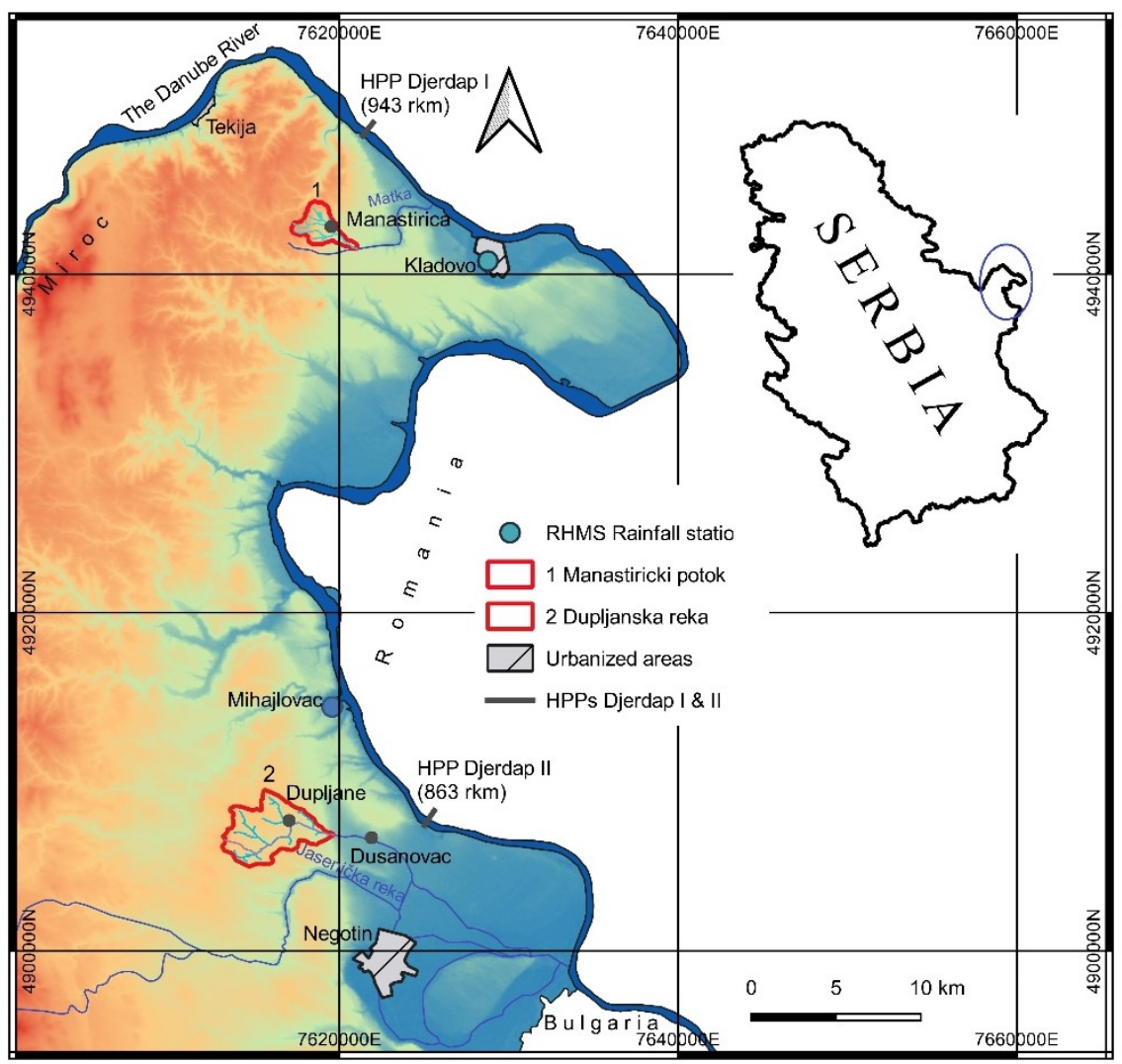

Figure 1. Studied watersheds (EPSG: 6316)

With regard to pedological cover, the watershed of Manastirički potok consists of Haplic Luvisol $(90 \%)$ and Haplic Cambisol (Dystric, Skeletic) (10\%), while the watershed of Dupljanska reka is mainly covered by Rendzic Leptosol (58\%), Haplic Cambisol (Dystric, Skeletic) (27\%) and Haplic Luvisol (12\%). According to the CORINE Land Cover (2018), the land use of the watershed of Dupljanska reka is presented by agriculture area $(75 \%)$ and broad-leaved forest $(21 \%)$. The 
watershed of Manastirički potok has a better situation related to land use given that $51 \%$ of area is under broad-leaved forest and $41 \%$ is agriculture area.

\section{Methodology}

As the objective of this work is the estimation of the maximal discharge in subject watersheds given that there are no hydrological measurements, the conceptual model of the Soil Conservation Service and synthetic unit hydrograph theory, SCS-SUH (Snyder 1938, SCS 1956) is used as the most appropriate and reliable (Mishra \& Singh 2003). This combined method is explained in detail in research of Petrović et al. (2021) and described in Figure 2. The large set of watershed data are needed for its implementation and computations. At first, watershed geology, soil and land use data are used to define the watershed curve number $(C N)$ which is a core of SCS method. Then, it is possible to determine potential maximum retention, so the nett rainfall amount, which made the extreme direct - surface runoff, can be calculated. Watershed morphometry data are the input data for calculation of the watershed lag time which is a core of unit hydrograph, so the synthetic unit hydrograph and peak ordinate can be determined. Finally, this procedure enabled the computation of maximal discharge for Dupljanska reka and Manastirički potok on the $15^{\text {th }}$ September 2014.

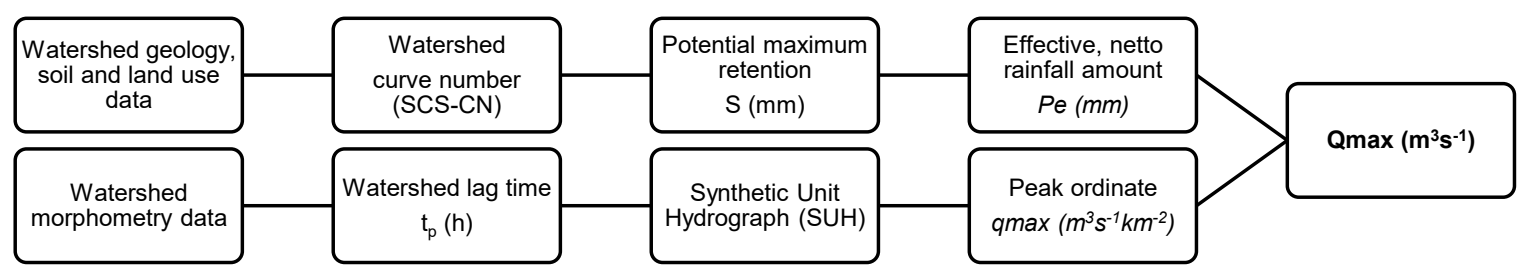

Figure 2. Description of the SCS-UH methodology for computing the maximal discharges

Soil erosion and sediment transport is intensified in the course of torrential rainfall episode and floods, so these processes have significant implications in the floods as natural hazards. In this paper, the mean annual suspended and bed-load sediment transport (G) is estimated so the value reveals the state of watersheds, i.e. to which extent this natural phenomenon is intensified by anthropogenic impact. The method of Poljakov-Kostadinov (Poljakov 1945, Kostadinov 1985) is used which is described in Figure 3.

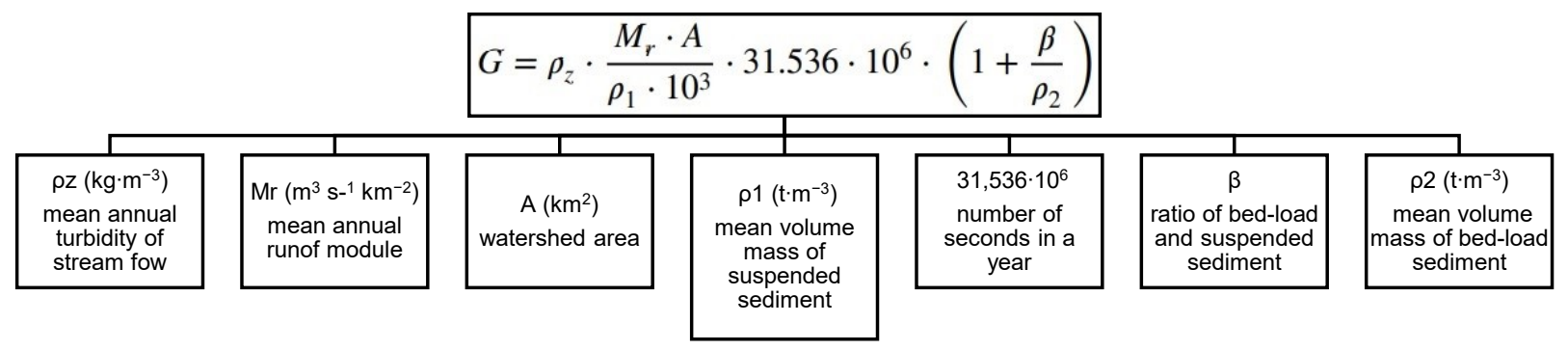

Figure 3. Description of the methodology for computing the mean annual sediment transport

\section{Results}

Special attention is given to definition of the most important watershed input parameters for computation of the maximal discharges on $15^{\text {th }}$ September 2014. The curve numbers for both 
studied watersheds according to all three soil moisture conditions (average - CNII, above average - CNIII and below average - CNI) are calculated and presented in Table 2. The CN for average moisture conditions reveals the hydrological properties of the soil cover and land use of the watersheds. The higher $\mathrm{CN}$, the higher peak discharge. The dominant hydrological class in both watersheds is B - according to the classification of soil types in Serbia for implementation of the SCS method given by Đorović (1984). As expected, due to more favourable land use conditions as explained in the section Study area, the watershed of Manastirički potok has the lower CN (65) in comparison with the watershed of Dupljanska reka (71). The lag time, which is a function of watershed length, length from the profile point to the point on the main river channel that is nearest to the watershed centroid as well as mean slope of river bed, is higher for Dupljanska reka (2.12h) than for Manastirički potok (1.48h). The shorter the lag time, the steeper the rising branch of the hydrograph.

Table 2. The lag time and curve numbers for studied watersheds

\begin{tabular}{|l|c|c|c|c|}
\hline \multicolumn{1}{|c|}{ Watersheds } & CNII $(\mathrm{I}=0.2 \mathrm{~S})$ & $\mathrm{CNIII}(\mathrm{I}<0.2 \mathrm{~S})$ & $\mathrm{CN}$ I $(\mathrm{I}>0.2 \mathrm{~S})$ & $\mathrm{T}_{\mathrm{lag}}(\mathrm{h})$ \\
\hline Dupljanska reka & 71 & 86 & 52 & 2.12 \\
\hline Manastirički potok & 65 & 82 & 45 & 1.48 \\
\hline
\end{tabular}

One of the most important input data are rainfall data which are taken from the rainfall stations of the Republic Hydrometeorological Service of Serbia - Mihajlovac for the Dupljanska reka and Kladovo for the Manastirički potok (cf. Figure 1). Considering the quantity of previous precipitations, we opted for CNIII for further calculations of extreme discharge on $15^{\text {th }}$ September 2014 (Table 3). Effective rainfall precipitation $\left(\mathrm{P}_{\mathrm{e}}, \mathrm{mm}\right)$ is calculated according to the SCS formula and time to peak $\left(T_{p}, h\right)$, time of recession $\left(T_{r}, h\right)$ and time base $\left(T_{b}=T_{p}+T_{r}\right)$ are defined according to the formulas of synthetic unit triangular hydrograph theory.

Finally, the peak hydrograph ordinate, $\mathrm{q}_{\max }\left(\mathrm{m}^{3} \mathrm{~s}^{-1} \mathrm{~mm}^{-1}\right)$ and maximal discharge, $\mathrm{Q}_{\max }\left(\mathrm{m}^{3} \mathrm{~s}^{-1}\right)$ are estimated for both watersheds on the event date. The specific maximal discharge, $\mathrm{q}_{\operatorname{maxsp}}\left(\mathrm{m}^{3} \mathrm{~s}^{-1} \mathrm{~km}^{-}\right.$ ${ }^{2}$ ) which is a function of maximal discharge and watershed area, is a valuable indicator if we want to compare runoff between two watersheds. The larger specific maximal discharge of Dupljanska reka $\left(5.49 \mathrm{~m}^{3} \mathrm{~s}^{-1} \mathrm{~km}^{-2}\right)$ is a result of larger $\mathrm{CN}$ as well as larger daily rainfall quantity measured at Mihajlovac $(180.3 \mathrm{~mm})$. Rainfall station Kladovo recorded less - $107.2 \mathrm{~mm}$ on the event date which altogether with lower $\mathrm{CN}$ gave double smaller specific maximal discharge $\left(2.59 \mathrm{~m}^{3} \mathrm{~s}^{-1} \mathrm{~km}^{-2}\right)$ for Manastirički potok. Consequently, the volume of torrential food wave (W), which is dependent on effective rainfall and watershed area, was quite higher in the Dupljanska reka watershed.

Table 3. Estimated maximal discharges for studied watersheds on $15^{\text {th }}$ September 2014

\begin{tabular}{|l|c|c|c|c|c|c|c|}
\hline Watersheds & $\mathrm{P}_{\mathrm{e}}(\mathrm{mm})$ & $\mathrm{T}_{\mathrm{p}}(\mathrm{h})$ & $\mathrm{T}_{\mathrm{b}}(\mathrm{h})$ & $\mathrm{q}_{\max }\left(\mathrm{m}^{3} \mathrm{~s}^{-1} \mathrm{~mm}^{-1}\right)$ & $\mathrm{Q}_{\max }\left(\mathrm{m}^{3} \mathrm{~s}^{-1}\right)$ & $q_{\operatorname{maxsp}}\left(\mathrm{m}^{3} \mathrm{~s}^{-1} \mathrm{~km}^{-2}\right)$ & $\mathrm{W}\left(\mathrm{m}^{3}\right)$ \\
\hline Dupljanska reka & 66.65 & 3.29 & 6.8 & 1.30 & 86.42 & 5.49 & $1,048,640.34$ \\
\hline Velika Kamenica & 24.81 & 2.73 & 5.37 & 0.51 & 12.73 & 2.59 & $122,109.70$ \\
\hline
\end{tabular}

Additionally, the maximal discharges according to the calculated maximal daily rainfall of a defined probability of occurrence, i.e. return period (method: Log Pearson III) at rainfall stations Kladovo and Mihajlovac (Table 4), also using the SCS-SUH model are computed. The dimensional curvilinear hydrographs of computed discharges of a defined probability of occurrence for different soil moisture conditions, i.e. $\mathrm{CN}$ value for both watersheds are presented in Figure 4. 
The probability of occurrence of reconstructed maximal discharges and return period of the $15^{\text {th }}$ September 2014 torrential food is specified and equals to 240-260 years for Dupljanska reka and 40-45 years for Manastirički potok. Regarding the estimation of return period, as already concluded in research of Petrović et al. (2021), there is a high impact of rainfall datasets and calculated rainfall of a given probability of occurrence which are used for the calculation of the maximal discharges of a specified probability of occurrence. Rainfall dataset for station Kladovo for the period of 48 years contains two similar maxima - $107.2 \mathrm{~mm}$ (recorded on 15.9.2014) and $107.3 \mathrm{~mm}$ (then $93.1 \mathrm{~mm}, 90.8 \mathrm{~mm}$ ) which implies that 100 return period rainfall will be probably higher than $107 \mathrm{~mm}$. Rainfall dataset for station Mihajlovac for the period of 57 years contains absolute maximum of $180.3 \mathrm{~mm}$ (recorded on 15.9.2014) and descending data series continues with $112 \mathrm{~mm}$, then $104.5 \mathrm{~mm}, 95.4 \mathrm{~mm}$ which implies that the difference between primary and secondary maximum will allow lower 100 year return period rainfall than $180.3 \mathrm{~mm}$. This entails the greater calculated rainfall of, for example, $1,0.5$ or $0.1 \%$ probability of occurrence for Mihajlovac than for Kladovo.

The 100 year return period maximal discharges is mainly used in hydrological studies and its value for Dupljanska reka for CNII is $32.3 \mathrm{~m}^{3} \mathrm{~s}^{-1}$ and for CNIII it is $63 \mathrm{~m}^{3} \mathrm{~s}^{-1}$. The maximal discharge of $1 \%$ probability of occurrence for Manastirički potok for CNII equals to $6.5 \mathrm{~m}^{3} \mathrm{~s}^{-1}$ and for CNIII equals to $17.2 \mathrm{~m}^{3} \mathrm{~s}^{-1}$.

Table 4. Maximal daily rainfall (P) of a defined probability of occurrence (p)/return period (T) at rainfall stations (source: Petrović et al. 2021)

\begin{tabular}{|c|c|c|c|}
\hline $\mathrm{T}$ & $\mathrm{p}$ & \multicolumn{2}{|c|}{$\mathrm{P}(\mathrm{mm})$} \\
\cline { 3 - 4 }$(\mathrm{yrs})$ & $(\%)$ & R. s. Kladovo & R. s. Mihajlovac \\
\hline 33 & 3 & 101.51 & 112.32 \\
\hline 50 & 2 & 110.54 & 124.30 \\
\hline 100 & 1 & 126.87 & 146.27 \\
\hline 200 & 0.5 & 144.53 & 171.46 \\
\hline 1000 & 0.1 & 191.38 & 242.26 \\
\hline
\end{tabular}

In the case of similar climate and rainfall characteristics, the great influence in calculations of mean annual sediment transport has the share of agricultural area and areas with poor vegetation. Here, the specific mean annual sediment transport, $G_{s p}\left(\mathrm{~m}^{3} \mathrm{yr}^{-1} \mathrm{~km}^{-2}\right)$ is a valuable indicator if we want to compare results between watersheds. As in Table 5, the watershed of Dupljanska reka has much higher sediment transport $\left(244 \mathrm{~m}^{3} \mathrm{yr}^{-1} \mathrm{~km}^{-2}\right)$ which is a consequence of land use patterns, than in case of the watershed of Manastirički potok (ca. $152 \mathrm{~m}^{3} \mathrm{yr}^{-1} \mathrm{~km}^{-2}$ ). Presented results indicate the urgent need for torrent and erosion control works (Petrović 2015) primarily in the watershed of Dupljanska reka.

Table 5. The mean annual sediment transport in studied watersheds

\begin{tabular}{|l|l|l|l|l|}
\hline Watershed & $\rho_{\mathrm{z}}\left(\mathrm{kg} \cdot \mathrm{m}^{-3}\right)$ & $\beta$ & $\mathrm{G}\left(\mathrm{m}^{3} \mathrm{yr}^{-1}\right)$ & $\mathrm{G}_{\mathrm{sp}}\left(\mathrm{m}^{3} \mathrm{yr}^{-1} \mathrm{~km}^{-2}\right)$ \\
\hline Dupljanska reka & 1.771 & 0.409 & 3847.57 & 244.49 \\
\hline Manastirički potok & 0.903 & 0.463 & 747.35 & 151.84 \\
\hline
\end{tabular}




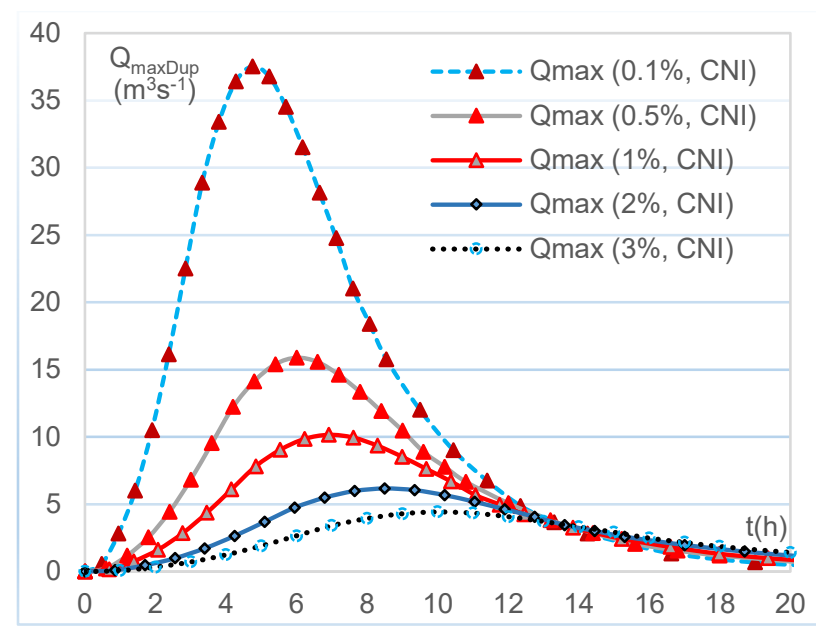

(a) $\mathrm{Q}_{\max \text { Dup }}$ for $\mathrm{CNI}$

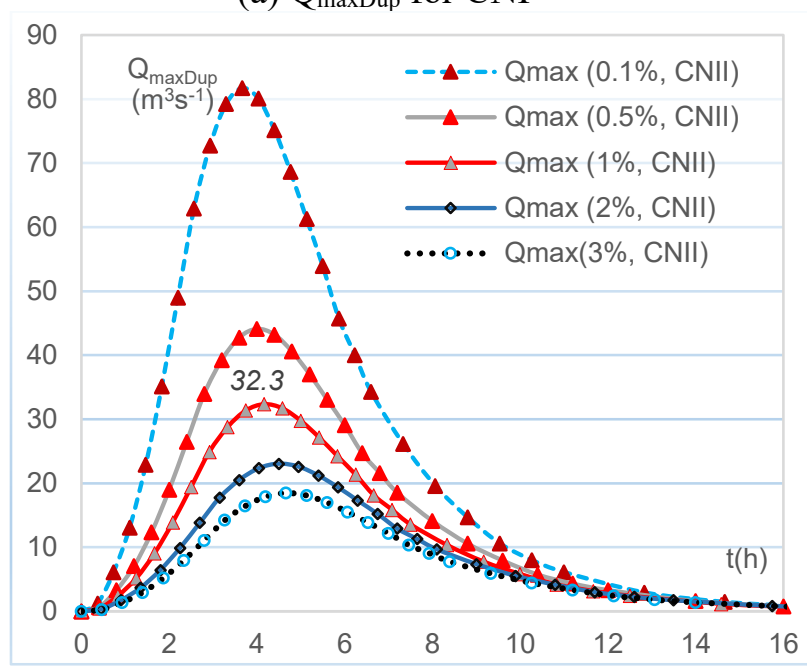

(b) $Q_{\operatorname{maxDup}}$ for CN II

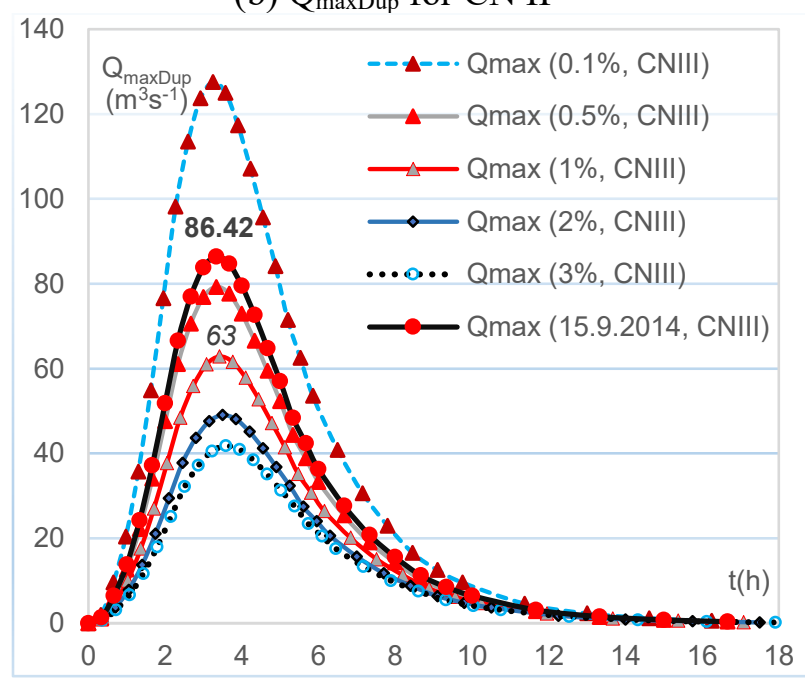

(c) $\mathrm{Q}_{\operatorname{maxDup}}$ for CNIII

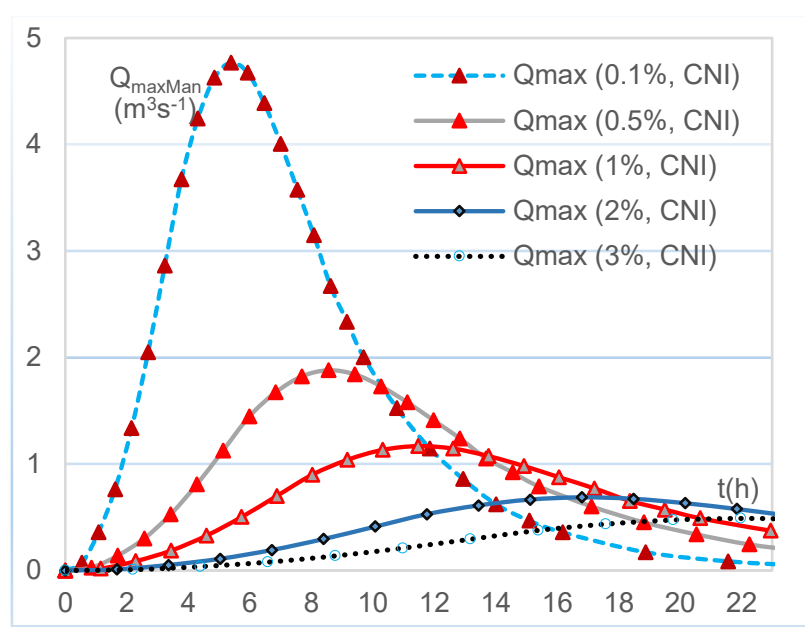

(d) $Q_{\operatorname{maxMan}}$ for CNI

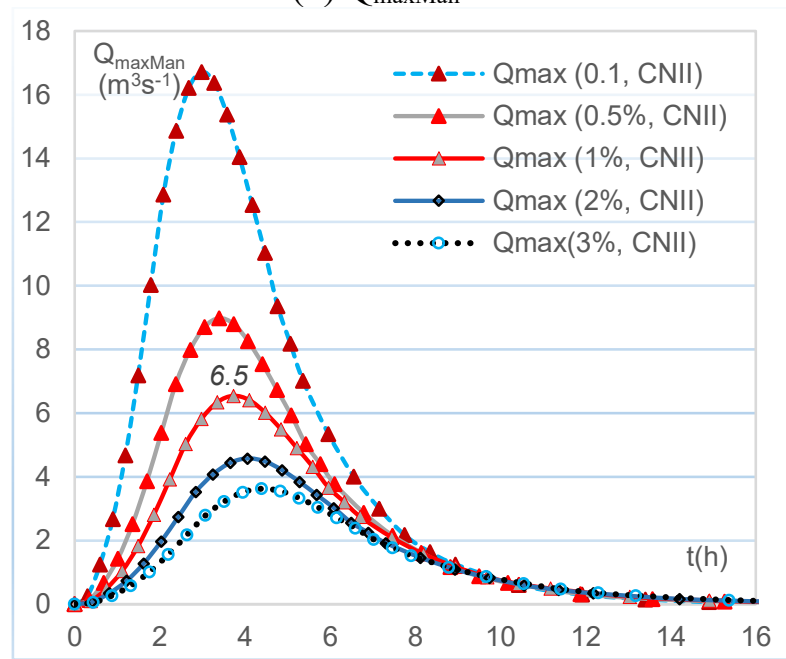

(e) $Q_{\operatorname{maxMan}}$ for CNII

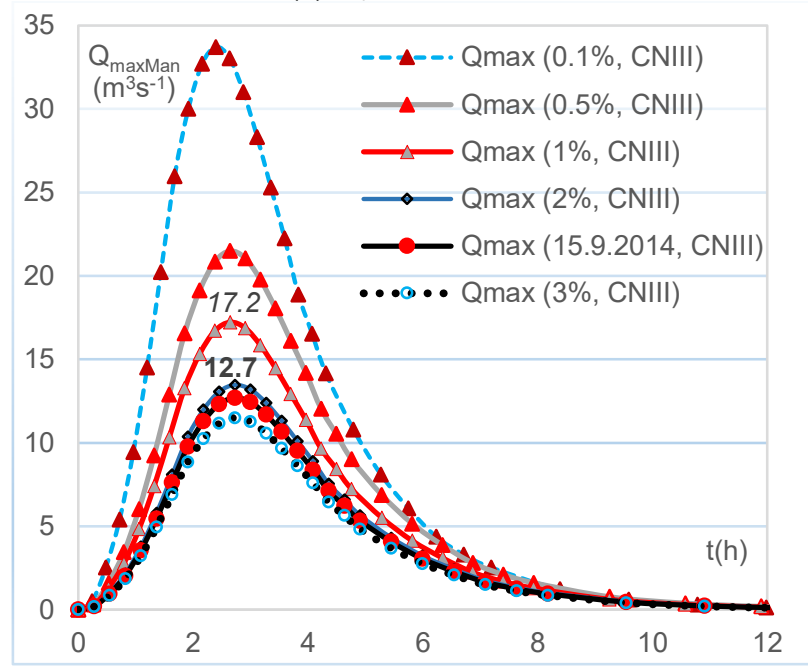

(f) $Q_{\operatorname{maxMan}}$ for CNIII

Figure 4. Maximal discharges of the Dupljanska reka - a, b, c, in case of CNI-II-III and Manastirički potok - d, e, f, in case of CN I-II-III 


\section{Conclusions}

The implemented methodology enables the reconstruction of watershed flood responses associated with the extreme rain-storm and is widely used in Serbia for the purpose of the hydraulic structures planning. Special attention is given to definition of the most important watershed input parameters $-\mathrm{CN}$ and lag time for computation of the maximal discharges on $15^{\text {th }}$ September 2014. In this paper, the maximal discharge for Dupljanska reka is estimated to $86.42 \mathrm{~m}^{3} \mathrm{~s}^{-1}$ and for Manastirički potok the estimated value is $12.73 \mathrm{~m}^{3} \mathrm{~s}^{-1}$. The September 2014 floods in the Eastern Serbia will remain historic given that they took 5 human lives and caused enormous material damage for local municipalities, so presented hydrological analysis is very important part of flood event documentation along with reports of municipalities' emergency headquarters.

The developed conceptual SCS-SUH models for Dupljanska reka and Manastirički potok may have also a significant role in forecasting procedures. Regarding the soil erosion and sediment transport as an accompanying processes to hydrological, RHMS Serbia stopped measurements in the watersheds due to high cost. The sediment transport in the course of specific torrential flood event could be estimated in next phase of this research. Also, anthropogenic impacts and social aspects of these natural and physical process need to be more explored and included (as in Manojlović et al. 2018 \& 2021, Perić \& Cvetković 2019, Cvetković \& Svrdljin 2020) which also could be one of the extensions of presented paper.

\section{References}

Cvetković V, Svrdlin M (2020) Vulnerability of women to the consequences of naturally caused disasters: the Svilajnac case study. Bezbednost 62(3): 43-61. (In Serbian) https://doi.org/10.5937/bezbednost2003043C

Đokanović SM (2016) Intense precipitation as a landslide triggering factor during September 2014 in the municipality Kladovo. Tehnika 71(6): 823-830. (In Serbian) https://doi.org/10.5937/tehnika1606823D

Djorović M (1984) Determination of soil Hydrologic class. Vodoprivreda 87:57-60 (In Serbian)

Kostadinov S (1985) Research of sediment transport regime in torrents of West and South-East Serbia. Dissertation, University of Belgrade (in Serbian)

Manojlovic S, Antić M, Santic D et al. (2018) Anthropogenic Impact on Erosion Intensity: Case Study of Rural Areas of Pirot and Dimitrovgrad Municipalities, Serbia. Sustainability 10 (3): 826 https://doi.org/10.3390/su10030826

Manojlović S, Sibinović M, Srejić T, Hadud A, Sabri I (2021) Agriculture Land Use Change and Demographic Change in Response to Decline Suspended Sediment in Južna Morava River Basin (Serbia). Sustainability, 13, 3130. https://doi.org/10.3390/su13063130

Mishra SK, Singh VP (2003) SCS-CN Method. In: Soil Conservation Service Curve Number (SCS-CN) Methodology. Water Science and Technology Library, vol 42, pp 84-146. Springer, Dordrecht. https://doi.org/https://doi.org/10.1007/978-94-017-0147-1_2

Perić J, Cvetković V (2019) Demographic, socio-economic and phycological perspective of risk perception from disasters caused by floods: case study of Belgrade. International Journal of Disaster Risk Management 1(2): 31-43. https://doi.org/10.18485/ijdrm.2019.1.2.3

Petrović A, Kostadinov S, Dragićević S (2014) The inventory and characterization of torrential food phenomenon in Serbia. Polish Journal of Environmental Studies 23:823-830

Petrović A (2015) Challenge of torrential food risk management. Journal of the Geographical Institute "Jovan Cvijić" SASA 65:131-143. https://doi.org/10.2298/IJGI1502131P 
Petrović AM, Novković I, Kostadinov S (2021) Hydrological analysis of the September 2014 torrential floods of the Danube tributaries in the Eastern Serbia. Natural Hazards 108(1): 1373-1387. https://doi.org/10.1007/s11069-021-04737-2

Poljakov BV (1948) Hydrological calculations for designing the structure at streams in small watersheds. GEI, Leniningrad (In Russian)

Soil Conservation Service (1956) Hydrology, National Engineering Handbook. Soil Conservation Service, Washington DC

Snyder FF (1938) Synthetic unit-graphs. Eos Trans AGU 19(1): 447-454. https://doi.org/10.1029/TR019i001p00447

Tošić I, Unkašević M (2014) Analysis of wet and dry periods in Serbia. International Journal of Climatology 34: 1357-1368. https://doi.org/10.1002/joc.3757

Tošić I, Unkašević M, Putniković S (2017) Extreme daily precipitation: the case of Serbia in 2014. Theoretical and Applied Climatology 128: 785-794. https://doi.org/10.1007/s00704-016-1749-2 